\title{
Maternal Outcome in Teenage Pregnancy (16-19 Years)
}

\author{
Dr. Anjani Shrivastav ${ }^{1}$, Dr. Aarti Jiyani ${ }^{2}$, Dr. Nilam Prajapati ${ }^{3}$ \\ ${ }^{1}$ Associate Professor, Department of Obstetrics and Gynecology, New civil Hospital, Surat, India \\ ${ }^{2}$ 2nd year resident, Department of Obstetrics and Gynecology, New civil Hospital, Surat, India \\ ${ }^{3}$ Assistant Professor, Department of Obstetrics and Gynecology, New civil Hospital, Surat, India
}

\begin{abstract}
Introduction: Adolescent pregnancy is widely recognized as one of the most complex and serious social, economic and health related problems throughout the world. Adolescent pregnancy is a high risk pregnancy. Outcome is less satisfactory than of a pregnancy in general population. Aims and Objective: This study aimed to find the maternal outcome in teenage pregnancy (16-19 years). Material and Method: Cases of teenage pregnancies (16-19 years) admitted in labour room of New Civil Hospital, Surat during the study period of April 2014 to March 2015. Data was collected through interviews and by observations using the predesigned proforma. The first contact with the subject for data collection began immediately after delivery of baby. Result: In this study $69 \%$ of subjects were associated with complication. The major maternal complications were anaemia $60.00 \%$, hypertensive disorder of pregnancy $37.00 \%$, Preterm labour 45\%. Conclusion: From present study we found that there are maternal complications like anaemia, eclampsia, preeclampsia were higher in teenage pregnancy as compared to general population. For pregnant adolescent attending the antenatal clinic, extra care should be taken to ensure that the minimum number of antenatal visits is made. Appropriate and adequate counseling on different antenatal services are to be offered to them.
\end{abstract}

Keywords: Adolescent, Teenage pregnancy, observational study, maternal outcomes.

\section{Introduction}

Adolescent pregnancy is widely recognized as one of the most complex and serious social, economic and health related problems throughout the world. Adolescent pregnancy is a high risk pregnancy. Outcome is less satisfactory than of a pregnancy in general population.

Adolescent pregnancy can have adverse consequences both for mother and child.

A wide range of issue and concerns faced by adolescent of India include nutritional deficiencies, reproductive health problems, STIs, and mental and physical stress related problems.

Obstetric risks like $\mathrm{PIH}$, preeclampsia, eclampsia, preterm labour and perinatal morbidity, mortality are more common in adolescent pregnancies.Knowledge of contraception for adolescent needs to be highly effective for prevention of psychological problems and adolescent pregnancy complications.

About 16 million adolescent girls give birth every year, most in low and middle income countries ${ }^{4}$. Still birth and new born death are $50 \%$ higher among infants of adolescent mothers than among infants of women aged 2029 years ${ }^{5}$.Girls and women from low socioeconomic class are at approximately ten times at risk of becoming teenage mother as compared with high socioeconomic class ${ }^{6}$.

\section{Aims And Objectives}

1. To evaluate the effect of pregnancy in teenage girls (1619 years).
2. To evaluate maternal outcomes in teenage pregnancy (1619 years).

\section{SUBJECTS AND METHODS}

\section{Source of data}

Cases of teenage pregnancies (16-19 years) admitted in labour room of New Civil Hospital, Surat during the study period of April 2014 to March 2015

\section{Methods of collection of data}

subjects with teenage (16-19 years) pregnancy of 24 to 40 weeks admitted to labour room of New Civil Hospital, Surat. Data was collected through interviews and by observations using the predesigned proforma. The first contact with the subject for data collection began immediately after delivery of baby.

\section{Observation and Discussion}

Distribution of subjects according to maternal age:

\begin{tabular}{|c|c|c|}
\hline Age & NO. of subjects $(n-100)$ & Percentage\% \\
\hline 16 years & 4 & $04.0 \%$ \\
\hline 17 years & 5 & $05.0 \%$ \\
\hline 18 years & 39 & $39.0 \%$ \\
\hline 19 years & 52 & $52.0 \%$ \\
\hline
\end{tabular}

- The above table shows that $91 \%$ of subjects had completed 18 years.

- 5\% of subjects had completed 17 years and $4 \%$ of subjects had completed 16 years of age.

- Mean age of my study was $18.4 \pm 1.06$ years. 


\section{International Journal of Science and Research (IJSR) \\ ISSN (Online): 2319-7064}

Index Copernicus Value (2013): 6.14 | Impact Factor (2015): 6.391

Comparison of our study with general population for term and preterm delivery:

\begin{tabular}{|l|c|c|}
\hline & Term Delivery & Preterm Delivery \\
\hline Teenage pregnancy(n-100) & $55(55 \%)$ & $45(45 \%)$ \\
\hline General population(n-7697) & $7256(94.27 \%)$ & $441(5.73 \%)$ \\
\hline
\end{tabular}

- On comparison with general population rate of preterm delivery was higher than term delivery which was statistically significant ( $\mathrm{p}$-value $<0.05$ )

Distribution of subjects according to associated complications on admission:

\begin{tabular}{|c|c|}
\hline Associated Complications & No. of Subject $(n-100)$ \\
\hline Anaemia & 45 \\
\hline Preterm labour & 35 \\
\hline Eclampsia & 19 \\
\hline Preeclampsia & 14 \\
\hline PROM & 13 \\
\hline Chorioamnionitis & 01 \\
\hline
\end{tabular}

- The above table shows that most common associated complication was anaemia. Second most common complication was preterm labour and third most common complication was eclampsia.

Distribution of subjects according to mode of delivery in teenage pregnancy:

\begin{tabular}{|c|c|c|c|}
\hline Mode of Delivery & $\begin{array}{c}\text { No. of } \\
\text { subjects } \\
(n-100)\end{array}$ & $\begin{array}{c}\text { Genarel } \\
\text { Population } \\
(n-7570)\end{array}$ & P-Value \\
\hline Vaginal delivery & $69(69 \%)$ & $5645(74.57 \%)$ & $<0.05$ \\
\hline LSCS & $28(28 \%)$ & $1832(24.20 \%)$ & $<0.05$ \\
\hline Instrumental delivery & $3(3 \%)$ & $93(1.23 \%)$ & $>0.05$ \\
\hline
\end{tabular}

- The above table shows that $69 \%$ of subjects were delivered vaginaly, either full term or preterm delivery.

- $\quad 28 \%$ subjects were delivered by LSCS and $3 \%$ subjects were delivered instrumentally.

- On comparison, rate of vaginal delivery was lower in teenage subjects than general population which was statistically significant $(<0.05)$.

Distribution of subjects according to indication of LSCS in teenage pregnancy:

\begin{tabular}{|c|c|c|c|}
\hline Indication of LSCS & $\begin{array}{c}\text { NO.OF } \\
\text { Subbjects } \\
(\mathrm{n}-28)\end{array}$ & $\begin{array}{c}\text { Genarel } \\
\text { Population } \\
(\mathrm{n}-1308)\end{array}$ & $\begin{array}{c}\text { P- } \\
\text { Value }\end{array}$ \\
\hline CPD & $09(32.15 \%)$ & $384(29.35 \%)$ & $>0.05$ \\
\hline $\begin{array}{c}\text { Eclampsia with } \\
\text { unfavorable cervix }\end{array}$ & $05(17.86 \% \%)$ & $60(4.60 \%)$ & $<0.05$ \\
\hline $\begin{array}{c}\text { MSL with unfavorable } \\
\text { cervix }\end{array}$ & $05(17.86 \%)$ & $264(20.29 \%)$ & $>0.05$ \\
\hline $\begin{array}{c}\text { Foetal distress in 1 } \\
\text { of labour stage }\end{array}$ & $03(10.71 \%)$ & $288(22.01 \%)$ & \\
\hline Non progress of labour & $03(10.71 \%)$ & $132(10.01 \%)$ & $>0.05$ \\
\hline $\begin{array}{c}\text { Severe oligohydramnios } \\
\text { with IUGR }\end{array}$ & $02(07.14 \%)$ & $33(2.52 \%)$ & $>0.05$ \\
\hline Breech & $01(3.57 \%)$ & $147(11.23 \%)$ & \\
\hline
\end{tabular}

- The above table shows that most common indication of LSCS in our subjects was CPD that was $32 \%$ the possible explanation could be underdevelopment of pelvis in younger mothers.

- Second most common indication was eclampsia with unfavorable cervix, which was $21 \%$.

\section{Distribution of maternal complications in subjects}

(overall):

\begin{tabular}{|c|c|c|c|}
\hline Maternal Complication & $\begin{array}{c}\text { No. of } \\
\text { Subjects } \\
(\mathrm{n}-100)\end{array}$ & $\begin{array}{c}\text { General } \\
\text { Population } \\
(\mathrm{n}-7811)\end{array}$ & P-Value \\
\hline Anaemia & $60(60 \%)$ & $1851(23.7 \%)$ & $<0.05$ \\
\hline Preterm labour pain & $45(45 \%)$ & $441(05.6 \%)$ & $<0.01$ \\
\hline Preeclampsia & $14(14 \%)$ & $499(06.4 \%)$ & $>0.07$ \\
\hline Eclampsia & $12(12 \%)$ & $90(01.6 \%)$ & $<0.05$ \\
\hline Hypertension & $11(11 \%)$ & $289(03.7 \%)$ & $<0.05$ \\
\hline Chorioamnionitis & $01(01 \%)$ & $05(0.06 \%)$ & $>0.08$ \\
\hline Mortality & 00 & $47(0.6 \%)$ & \\
\hline
\end{tabular}

- The most common complication in subjects was anaemia that was $49 \%$. Second most common complication was preterm labour that was $35 \%$.

- On comparison with general population rate of anaemia was significantly higher in our study ( $\mathrm{p}$ value-<0.05)

- Comparison of our study to another study:

\begin{tabular}{|c|c|c|c|c|}
\hline $\begin{array}{c}\text { Mode of } \\
\text { delivery }\end{array}$ & $\begin{array}{c}\text { Our } \\
\text { study }\end{array}$ & $\begin{array}{c}R N \\
\text { chaudhri et } \\
\text { al (2007) }\end{array}$ & $\begin{array}{c}\text { A K Sharma } \\
\text { et al (2003) }\end{array}$ & $\begin{array}{c}\text { IMR } \\
\text { Goodnewardene } \\
\text { et al (2005) }\end{array}$ \\
\hline $\begin{array}{c}\text { Vaginal } \\
\text { delivery }\end{array}$ & $69 \%$ & $85.7 \%$ & $95.3 \%$ & $94.4 \%$ \\
\hline LSCS & $28 \%$ & $08.3 \%$ & $04.9 \%$ & $06.3 \%$ \\
\hline $\begin{array}{c}\text { Instrumental } \\
\text { delivery }\end{array}$ & $03 \%$ & $06.0 \%$ & & $02.4 \%$ \\
\hline $\begin{array}{c}\text { Maternal } \\
\text { Complications }\end{array}$ & \multicolumn{4}{|l}{} \\
\hline Anaemia & $49 \%$ & $28.5 \%$ & $34.7 \%$ & $50.5 \%$ \\
\hline $\begin{array}{c}\text { Preterm } \\
\text { delivery }\end{array}$ & $43 \%$ & $27.7 \%$ & $03.2 \%$ & $10.7 \%$ \\
\hline Preeclampsia & $14 \%$ & $19.4 \%$ & $25.0 \%$ & $11.8 \%$ \\
\hline Eclampsia & $12 \%$ & $04.8 \%$ & $05.4 \%$ & $06.8 \%$ \\
\hline
\end{tabular}

\section{Discussion}

The incidence of teenage pregnancy shows marked variation in developed and developing countries ${ }^{11}$. As per DLHS ${ }^{12}$ 3(District level Household and Facility Survey), in India, over all incidence of adolescent pregnancy is $5.6 \%$ (rural $6.4 \%$ and urban $3.5 \%$ ), there is wide rangeof variation among states.Gujrat has $3.4 \%$ of adolescent pregnancy. There are some extrinsic factors such as inadequate prenatal care, illiteracy, and poor socioeconomic conditions that affect the outcome of pregnancy in teenage girls ${ }^{7-9}$. Several medical complications like preterm birth, poor maternal weight gain, pregnancy induced hypertension, anaemia and sexually transmitted diseases are strongly associated with teenage pregnancy. 


\section{International Journal of Science and Research (IJSR) \\ ISSN (Online): 2319-7064 \\ Index Copernicus Value (2013): 6.14 | Impact Factor (2015): 6.391}

In our study $52 \%$ of subjects were 19 years of age and $48 \%$ of subjects were 18 to 16 years of age. $96 \%$ of subjects were primi gravida and $4 \%$ of subjects were second gravida.

Early marriage in our society are associated with low level of schooling and education as well as early pregnancies. Attainment of higher education is associated with better awareness and wisdom, and consequently an urge for professional pursuit and desire for economic independence. This in turn to leads to late marriage and late conception preventing unintended adolescent pregnancies.

In our study $52 \%$ of subjects were emergency admission who had not taken single ANC visit, 23\% subjects were registered subjects and $25 \%$ were referred from rural area.

In our study $69 \%$ of subjects were delivered vaginaly, either full term or preterm delivery. $28 \%$ subjects were delivered by LSCS and 3\% subjects were delivered instrumentally. On comparison, rate of vaginal delivery was lower in teenage subjects than general population which was statistically significant $(<0.05)$. most common indication of LSCS in our subjects was CPD that was $32 \%$ the possible explanation could be underdevelopment of pelvis in younger mothers.Second most common indication was eclampsia with unfavorable cervix, which was $21 \%$.

Maternal complication like anaemia and preeclampsia were comparable with other study while rates of preterm delivery and eclampsia were higher in our study. In India Aznar et $\mathbf{a l}^{10}$ had observed incidence of $10 \%$ eclampsia in their adolescent group and the frequency was more in girls less than 15 years (ACOG, 1998; National Health Statistics, 1997). He had also reported increase in primary cesarean section by $28 \%$ in patients of 15 years or below.

\section{Conclusion}

From present study we found that there are maternal complications like anaemia, eclampsia, pre-eclampsia were higher in teenage pregnancy as compared to general population. Also we found that neonatal complications like low birth weight, prematurity, IUGR were higher as compared to general population. The adverse outcome of teenage pregnancy could be attributed not only to lower maternal age but also to their relatively disadvantaged socioeconomic background. Efforts need to be directed towards strict enforcement of laws prohibiting teenage marriage in India. Access to quality health services that are gender - sensitive and adolescent - friendly should be ensured.

\section{References}

[1] Khanna AT. Adolescent Health: issues and concerns in India. Health Millions. 1995;21(3):29-30.

[2] Bhatia BD, Chandra R. Adolescent mother. Ind J Matern Child Health. 1993;4(3):67-70.

[3] Statistcs on Teen Pregnancy. National Campaign To Prevent Teen Pregnancy.

[4] The National Campaign To Prevent Teen Pregnancy. Not just another single issue :Teen pregnancy prevention's linked to other critical social issues PDF(147KB). 2002. Retrieved May 27, 2006.

[5] Furstenberg FF, Levine JA, Brooks-Gunn J. The children of teenage mothers: Patterns of early childbearing in two generations. Fam Plann Perspect. 1990;22(2):54-61. Doi:10.2307/2135509. JSTOR 2135509. PMID 2347409.

[6] Swann C, Bowe K, McCormick G, Kosmin M. Teenage Pregnancy and parenthood: A review of reviews. London: HAD. 2003.

[7] Bhaduria S. Teenage pregnancy: A retrospective study. J Obstet Gynecol India. 1991;41:454-6.

[8] Kale KM. Socio-medical correlates of teenage pregnancy. J Obstet Gynecol India. 1996;46:180-4.

[9] Pal A, Gupta KB, Randhawa I. Adolescent pregnancy: A high-risk group. J Ind Med Assoc. 1997;95:127-8.

[10] Aznar R, Bennet AE. Pregnancy in the adolescent girl. Am Obstet Gynaec. 1961;81:934.

[11] http://WWW.unfa.org/public/home/factsseets/young_pe ople\#getfects as accessed on 24 September 2012.

[12] Hppt://WWW.rchiips.org/PRCH-3.html as accessed on 24 September 2012. 